\title{
Interplay of halogen and hydrogen bonding in a series of heteroleptic iron(III) complexes
}

\author{
Authors: Raúl Díaz-Torres, ${ }^{1}$ Jorge Echeverría, ${ }^{2}$ Oliver Loveday, ${ }^{2}$ Phimphaka Harding ${ }^{* 1}$ and David J. \\ Harding*1 \\ ${ }^{1}$ Functional Materials and Nanotechnology Centre of Excellence, Walailak University, Thasala, \\ Nakhon Si Thammarat, 80160, Thailand. \\ 2 Departament de Química Inorgànica i Orgànica \& IQTC-UB, Universitat de Barcelona, Martí i \\ Franquès, 1-11, 08028 Barcelona, Spain.
}

E-mail: hdavid@mail.wu.ac.th or kphimpha@mail.wu.ac.th

\section{ABSTRACT}

The influence of the halogen substituent on crystal packing and redox properties is investigated in a series of heteroleptic complexes [Fe(qsal-X)(dipic)].MeOH (qsal-X = 4-halogen-2-[(8quinolylimino)methyl]phenolate; dipic = 2,6-pyridinedicarboxylate; $X=F \mathbf{1}, \mathrm{Cl} 2, \mathrm{Br} 3$ and I 4). Compounds 1 and $\mathbf{2}$ exhibit triclinic symmetry $(P \overline{1})$, whereas 3 and $\mathbf{4}$ crystallise in monoclinic $P 2_{1} / \mathrm{n}$. The crystal packing shows self-sorting of the ligands with $\pi-\pi$ interactions between the qsal-X ligands and overlap of the dipic ligands to form a 1D chain, that is supported by $\mathrm{C}-\mathrm{H} \cdots \mathrm{O}$ interactions. In $\mathbf{1}$ and $\mathbf{2}$, the cross-section of the 1D chain is square, while for $\mathbf{3}$ and $\mathbf{4}$, it is rectangular. In the former, the dipic ligands interact through $C=0 \cdots \pi$ interactions, while $\pi-\pi$ interactions are found in $\mathbf{3}$ and $\mathbf{4}$. Neighbouring chains are connected via $\pi-\pi$ interactions involving the quinoline rings, but their relative position is driven by the preference of $\mathbf{1}$ and $\mathbf{2}$, for $\mathrm{C}-\mathrm{H} \cdots \mathrm{X}$ interactions, whereas $\mathbf{3}$ and $\mathbf{4}$ form $\mathrm{O} \cdots \mathrm{X}$ halogen bonds. The nature and topology of the electron density of these interactions have been investigated using molecular electrostatic potential (MEP) mapping, quantum theory of atoms in molecules (QTAIM) and 'non-covalent interactions' ( $\mathrm{NCl}$ ) analysis. UV-Visible experiments show MLCT bands associated with the qsal-X ligands, confirming the structure is stable in solution. Electrochemical studies reveal slight tuning of the $\mathrm{Fe}^{3+} / \mathrm{Fe}^{2+}$ redox couple showing a linear relationship between $\mathrm{E}^{\prime \circ}$ and the Hammett parameter $\sigma_{\mathrm{p}}$.

\section{INTRODUCTION}

Crystal engineering involves the identification and use of robust non-covalent interactions in the design of compounds with predictable structures, and desirable physical properties. ${ }^{1-6}$ Despite the myriad of crystal structures now known, this remains a challenging goal and requires a thorough 
understanding of intermolecular interactions in order to design new crystalline structures. For many years hydrogen bonding was the most widely used strategy in crystal engineering, ${ }^{7}$ but more recently halogen bonding has emerged as an alternative as it is also highly directional and robust. Halogen bonding occurs due to the formation of a $\sigma$-hole along the $\mathrm{C}-\mathrm{X}$ bond and is generally strongest for iodine as it contains the most polarizable electron cloud. ${ }^{8}$ Using halogen bonding, a range of supramolecular systems have been designed, but the most commonly reported are purely organic compounds. ${ }^{9-13}$ In contrast, the use of halogen bonding in coordination complexes, which are among the most diverse structures found in chemistry, remains comparatively unexplored. ${ }^{14}$ In the studies that have been reported, three general strategies have emerged: firstly the design of ligands with an acceptor and donor in the same ligand (type i), ${ }^{15-17}$ secondly cocrystals with either a neutral or cationic complex and halogen bonding donors (type ii) ${ }^{18-24}$ and lastly complexes with two different ligands with one acting as the acceptor and the other the donor (type iii). The latter class typically uses halopyridine ligands and chelates such as $\beta$-diketonates to balance the charge of the metal and satisfy the need for octahedral geometry. ${ }^{25,26}$ While this approach has met with some success, a problem has been the monodentate nature of the pyridine ligands and the formation of cis or trans geometric isomers which limits controllability.

i)

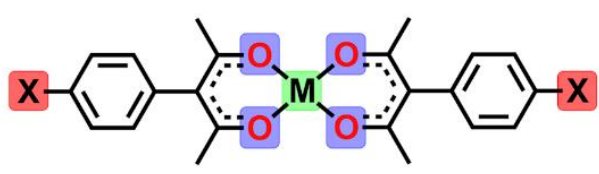

Aakeröy 2011

ii)

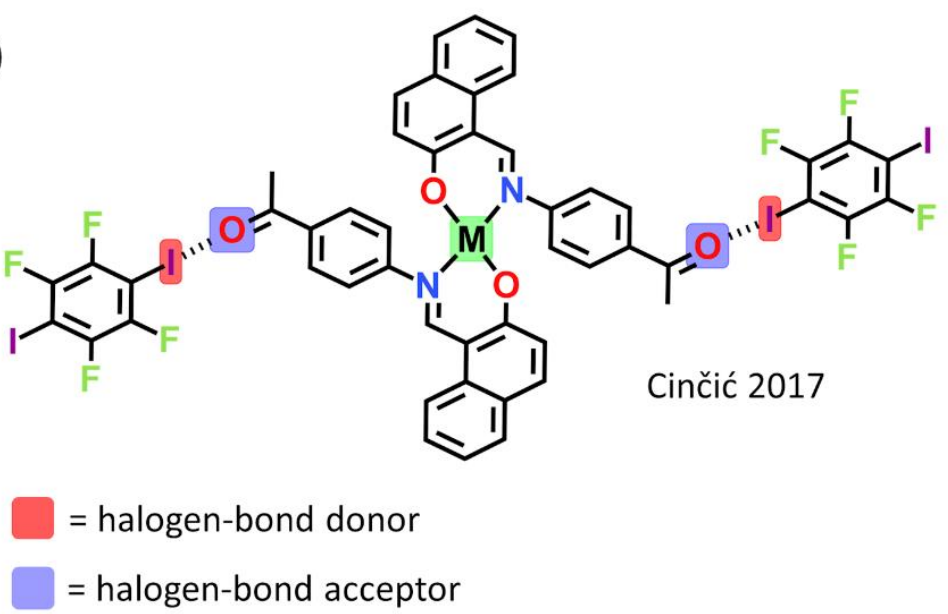

iii)

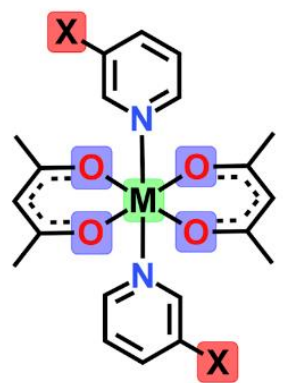

Đaković 2018

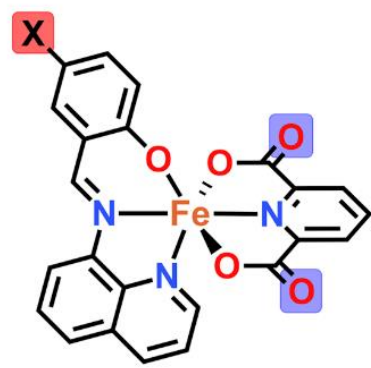

This work

Scheme 1 Three general strategies for halogen bond formation in coordination complexes: (i) donor and acceptor halogen bonding in the same ligand, (ii) cocrystal between complexes and halogen bonding donors and (iii) donor and acceptor halogen bonding in two different ligands. 
In seeking greater control, we selected two planar tridentate ligands for use in complexes of the general formula [Fe(L1)(L2)]. As both ligands are planar, only a mer geometry can form, increasing control on the supramolecular array. One of the ligands is quinolylsalicylaldimine (Hqsal-X) which allows easy introduction of the halogen bond donor. Our work with this ligand in spin crossover complexes, $\left[\mathrm{Fe}(\mathrm{qsal}-\mathrm{X})_{2}\right] \mathrm{A}(\mathrm{A}=\text { anion })^{27-29}$ shows that it produces reliable $1 \mathrm{D}$ chains through $\pi-\pi$ interactions between the large $\pi$-clouds of the qsal-X ligand, while still allowing the halogen to participate in halogen bonding. The other ligand we have chosen is 2,6-pyridinedicarboxylate (dipic) which is expected to act as the halogen bond acceptor and as it is dianionic allows neutral complexes to be made with $\mathrm{Fe}(\mathrm{III})$. Interestingly, [cation $]_{\mathrm{n}}\left[\mathrm{M}\left(\text { dipic }_{2}\right)_{\text {] }}\right.$ complexes also engage in $\pi$ - $\pi$ stacking, although the structures are often held together through $\mathrm{H}$-bonding. ${ }^{30-33}$ In this study we aim to investigate how varying the identity of the halogen on the qsal-X ligand influences the degree of halogen bonding and how that impacts the packing in the heteroleptic complexes [Fe(qsal$\mathrm{X}$ )(dipic)] $\cdot \mathrm{MeOH}(\mathrm{X}=\mathrm{F} \mathrm{1}, \mathrm{Cl} \mathbf{2}, \mathrm{Br} 3$ and I 4). In this series we reveal how going from $\mathrm{F}$ to I subtly alters the structure and also demonstrate that despite being far from the metal centre, the halogen is still able to influence the position of the Fe ${ }^{I I / I I}$ redox couple.

\section{EXPERIMENTAL SECTION}

Materials. All reactions were carried out in aerobic conditions using commercial grade solvents for the synthesis of all compounds. The Hqsal-X ligands were synthesized according to literature methods. ${ }^{34}$ All chemicals were purchased from TCI Chemicals or Sigma-Aldrich and used as received.

\section{Synthesis of [Fe(qsal-F)(dipic)]·MeOH 1}

Hqsal-F (6.65 mg, $0.025 \mathrm{mmol}$ ) and 2,6-pyridinedicarboxylic acid ( $\mathrm{H}_{2}$ dipic) (4.18 mg, $\left.0.025 \mathrm{mmol}\right)$ were dissolved in $\mathrm{MeOH}(5 \mathrm{~mL})$ giving an orange solution. $\mathrm{NEt}_{3}(21 \mu \mathrm{L}, 0.075 \mathrm{mmol})$ was added and the solution was stirred for 5 min resulting in a change to dark orange. Next, blank $\mathrm{MeOH}(5 \mathrm{~mL})$ was layered on top of the previous solution. In a separate flask, $\mathrm{FeCl}_{3} \cdot 6 \mathrm{H}_{2} \mathrm{O}(6.75 \mathrm{mg}, 0.025 \mathrm{mmol})$ was dissolved in $\mathrm{MeOH}$ ( $3 \mathrm{~mL}$ ), filtered and then layered on top and left for 2 days. Black crystals (9.4 mg,

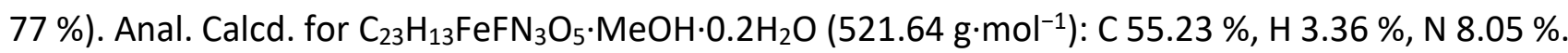
Found: C $54.97 \%$, H 3.05 \%, N $8.19 \%$. ESI ${ }^{-}$(m/z): 485.3 [Fe(dipic)(qsal-F)]'. IR Data (KBr, cm $\left.{ }^{-1}\right): 3452$ $\left(v_{\mathrm{O}-H}\right), 3059\left(v_{\mathrm{C}-\mathrm{H}}\right), 1669\left(v_{\mathrm{C}=\mathrm{O}}\right), 1603\left(v_{\mathrm{C}=\mathrm{N}}\right), 1335\left(v_{\mathrm{C}-\mathrm{O}}\right)$.

Compounds 2-4 were synthesized in an identical way substituting Hqsal-F with the appropriate Hqsal$\mathrm{X}$ ligand.

\section{Synthesis of [Fe(qsal-Cl)(dipic)]·MeOH 2}

Black crystals $\left(9.2 \mathrm{mg}, 73\right.$ \%). Anal. Calcd. for $\mathrm{C}_{23} \mathrm{H}_{13} \mathrm{BrFeN}_{3} \mathrm{O}_{5} \cdot 2 \mathrm{H}_{2} \mathrm{O}\left(581.95 \mathrm{~g} \cdot \mathrm{mol}^{-1}\right)$ : $\mathrm{C} 51.44 \%, \mathrm{H}$ $3.15 \%$, N 7.83 \%. Found: C 50.94 \%, H $2.62 \%$, N 7.76 \%. ESI' (m/z): 501.6 [Fe(dipic)(qsal-Cl)]-. IR Data $\left(\mathrm{KBr}, \mathrm{cm}^{-1}\right): 3408\left(v_{\mathrm{O}-\mathrm{H}}\right), 3047\left(v_{\mathrm{C}-\mathrm{H}}\right), 1671\left(v_{\mathrm{C}=\mathrm{O}}\right), 1602\left(v_{\mathrm{C}=\mathrm{N}}\right), 1333\left(v_{\mathrm{C}-\mathrm{O}}\right)$.

\section{Synthesis of [Fe(qsal-Br)(dipic)]·MeOH 3}


Black crystals (10.3 mg, $75 \%)$. Anal. Calcd. for $\mathrm{C}_{23} \mathrm{H}_{13} \mathrm{BrFeN}_{3} \mathrm{O}_{5} \cdot 1.2 \mathrm{H}_{2} \mathrm{O}\left(567.55 \mathrm{~g} \cdot \mathrm{mol}^{-1}\right): \mathrm{C} 48.57 \%, \mathrm{H}$ $2.73 \%$, N $7.39 \%$. Found: C $48.39 \%$, H $2.51 \%$, N $7.37 \%$. ESI- (m/z): 546.0 [Fe(dipic)(qsal-Br)]. IR Data $\left(\mathrm{KBr}, \mathrm{cm}^{-1}\right): 3441\left(v_{\mathrm{O}-\mathrm{H}}\right), 3067\left(v_{\mathrm{C}-\mathrm{H}}\right), 1666\left(v_{\mathrm{C}=\mathrm{O}}\right), 1599\left(v_{\mathrm{C}=\mathrm{N}}\right), 1333\left(v_{\mathrm{C}-\mathrm{O}}\right)$.

\section{Synthesis of [Fe(qsal-I)(dipic)]·MeOH 4}

Black crystals (12.2 mg, 82 \%). Anal. Calcd. for $\mathrm{C}_{23} \mathrm{H}_{13} \mathrm{FeIN}_{3} \mathrm{O}_{5} \cdot 1.4 \mathrm{H}_{2} \mathrm{O}\left(619.13 \mathrm{~g} \cdot \mathrm{mol}^{-1}\right)$ : $\mathrm{C} 44.60 \%, \mathrm{H}$ 2.57 \%, N 6.78 \%. Found: C $44.44 \%$, H 2.36 \%, N $6.78 \%$. ESI- (m/z): 593.8 [Fe(dipic)(qsal-I)]-. IR Data $\left(\mathrm{KBr}, \mathrm{cm}^{-1}\right): 3444\left(v_{\mathrm{O}-\mathrm{H}}\right), 3057\left(v_{\mathrm{C}-\mathrm{H}}\right), 1668\left(v_{\mathrm{C}=\mathrm{O}}\right), 1602\left(v_{\mathrm{C}=\mathrm{N}}\right), 1336\left(v_{\mathrm{C}-\mathrm{O}}\right)$.

\section{X-ray Crystallography}

The diffraction data of 1-4 were collected on a Rigaku SuperNova diffractometer with a HyPix 3000 detector using Cua radiation ( $\lambda=1.54184 \AA$ A). Data reduction, scaling, and absorption corrections were performed using CrysAlisPro. ${ }^{35}$ The structures were solved, and the space groups $P \overline{1}$ and $P 2_{1} / \mathrm{n}$ were determined by intrinsic phasing using ShelXT $\mathrm{T}^{36}$ and refined by full matrix least-squares minimization on $F^{2}$ using SHELXL. ${ }^{37}$ All non-hydrogen atoms were refined anisotropically. Hydrogen atoms were included in calculated positions and refined with isotropic thermal parameters, which were $1.2 \times$ or $1.5 x$ the equivalent isotropic thermal parameters of their parent carbon or oxygen atoms. All pictures were generated with OLEX2. ${ }^{38}$ Crystallographic data for the structures have been deposited with the Cambridge Crystallographic Data Centre (CCDC) 2075294-2075297. Powder X-ray diffraction data were measured on a Rigaku SuperNova diffractometer with a HyPix 3000 detector using Cu $\alpha$ radiation $(\lambda=1.54184 \AA$ ) . The samples were ground and then suspended in Fomblim $Y$ oil, and the data were collected between $2 \theta=5-80^{\circ}$.

\section{Physical measurements}

Infrared spectra $\left(4000-400 \mathrm{~cm}^{-1}\right)$ were recorded as $\mathrm{KBr}$ pellets on a PerkinElmer Spectrum One infrared spectrophotometer. Elemental analyses were carried out by using a Eurovector EA3000 analyzer. ESI-MS were carried out on a Bruker AmaZon X LCMS Mass Spectrometer. Electronic spectra were recorded in DCM at room temperature on a Avasoft UV-Vis spectrophotometer. Electrochemical studies were conducted using an Autolab type III controlled by a personal computer using Nova 1.10 software (Metrohm Autolab, The Netherlands). The three-electrode cell was comprised of a platinum disc ( $2.0 \mathrm{~mm}$ diameter) working electrode, an $\mathrm{Ag} / \mathrm{AgCl}(3.0 \mathrm{M} \mathrm{KCl})$, reference electrode and a platinum wire, counter electrode. A solution of the compounds $(0.2 \mathrm{mM})$ were prepared in $\mathrm{CH}_{2} \mathrm{Cl}_{2}$ that had been dried over molecular sieves with $\left[\mathrm{NBu}_{4}\right]\left[\mathrm{PF}_{6}\right](0.1 \mathrm{M})$ used as the supporting electrolyte. Under these conditions, the one-electron oxidation of [ $\left.\mathrm{Fe}\left(\eta-\mathrm{C}_{5} \mathrm{H}_{5}\right)_{2}\right]$ added to the test solutions as an internal calibrant was $\mathrm{E}^{\mathrm{O}^{\prime}}=0.52 \mathrm{~V}$.

\section{Computational methods}

All electron structure calculations were performed with Gaussian $16^{39}$ using the hybrid B3LYP functional along with Grimme's empirical correction for the dispersion energy (B3LYP-D3). ${ }^{40}$ We used the def2-TZVP basis set for all atoms. Interaction energies were corrected for the basis sets 
superposition error ( $B S S E$ ) by means of the counterpoise method and defined as $\triangle E_{B S S E}(A B)=E^{A B}(A B)$ $-E^{A B}(A)-E^{A B}(B)$, where $A B$ is the dimer composed of monomers $A$ and $B$. Crystallographic coordinates were used without further geometry optimisation. The topology of the electron density was analysed via the quantum theory of atoms in molecules (QTAIM) with AIMAll 14.11.23 ${ }^{41}$ on the B3LYP/def2TZVP wavefunction. $\mathrm{NCl}$ plots were generated with MultiWfn $3.7^{42}$ based on promolecular densities.

\section{RESULTS AND DISCUSSION}

\section{Synthesis and spectroscopic studies}

The complexes were synthetized by layered diffusion of $\mathrm{FeCl}_{3} \cdot 6 \mathrm{H}_{2} \mathrm{O}$ in $\mathrm{MeOH}$ on top of a solution of Hqsal-X (X = halogen), $\mathrm{H}_{2}$ dipic and $\mathrm{NEt}_{3}$ in $\mathrm{MeOH}$. The use of $\mathrm{MeOH}$ leads to rapid diffusion between the layers. This fact, together with the relatively low solubility of the final compounds in $\mathrm{MeOH}$, results in crystalline products in one or two days, in high yields ca. $75 \%$. The IR spectra reveal peaks around 1670 and $1600 \mathrm{~cm}^{-1}$, corresponding to the carbonyl group from the dipic moiety, and imine group from the qsal-X moiety, respectively, indicating the formation of the heteroleptic complexes. This fact is also confirmed by elemental analysis and mass spectrometry. We note that small peaks due to the homoleptic complexes are also observed, however they represent trace amounts as EA and PXRD confirm that the bulk material is consistent only with the heteroleptic complexes.

The UV-Visible spectra of 1-4 were recorded in DCM and are similar with two peaks at ca. 330 $\mathrm{nm}$ and $405 \mathrm{~nm}$, and a lower intensity wider band found at $530 \mathrm{~nm}$ (Figure 1). The peaks are typically observed in qsal-X systems and are assigned to $\pi-\pi^{*}$ and LMCT transitions, respectively; while the wide band corresponds to the dipic moiety. No solvatochromic effects were found in DMF and the data suggests that the compounds are stable in solution (Figure S1).

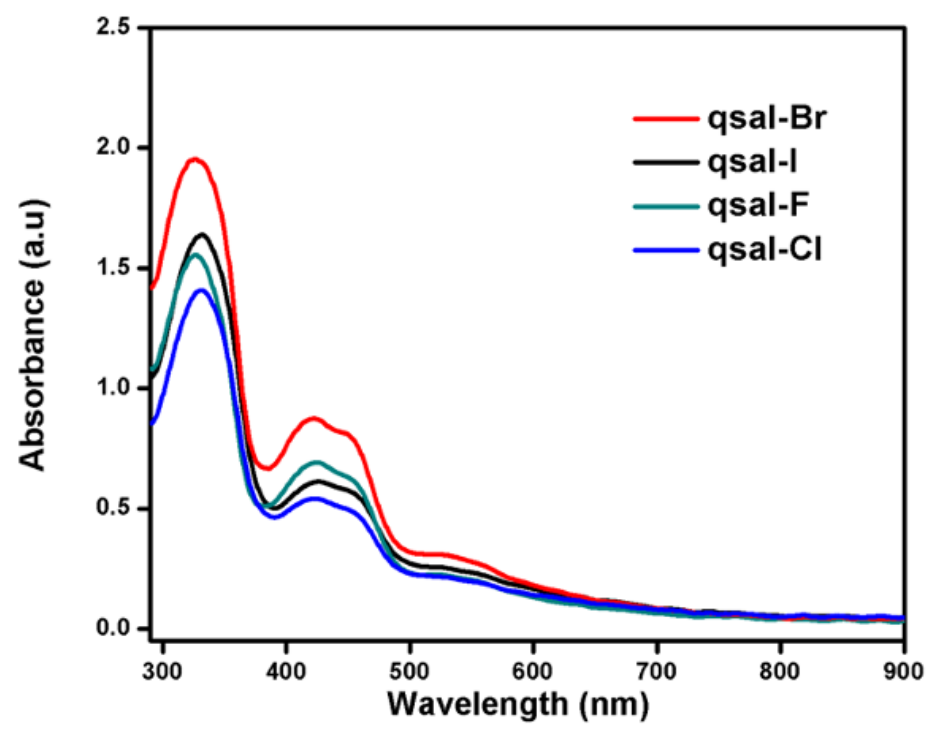

Figure 1 UV-Visible spectra of 1-4 in DCM at $0.001 \mathrm{M}$. 


\section{Structural studies}

The crystal structures of 1-3 were determined at $150 \mathrm{~K}$, while 4 was determined at room temperature. PXRD studies show that the crystal structures are reflective of the bulk materials (Figure S2). Depending on the qsal-X ligand, a different symmetry is observed. In the case of $\mathbf{1}$ and $\mathbf{2}$, both systems crystallize in triclinic $P \overline{1}$ with two molecules in the unit cell $\left(Z=2\right.$, ca. $V=1100 \AA^{3}$; Table S1). However, 3 and 4 crystallize in monoclinic symmetry (space group $P 2_{1} / n$ ) with four molecules in the unit cell $\left(Z=4\right.$, ca. $\left.V=2170 \AA^{3}\right)$. In all cases, the asymmetric unit shows a mononuclear complex [Fe(qsal-X)(dipic)] with a methanol solvent molecule (Figure 2). The Fe $\mathrm{III}^{\mathrm{II}}$ center is coordinated by one qsal-X ligand (through two nitrogens, $\mathrm{N}_{\text {imine }}$ and $\mathrm{N}_{\text {quinoline; }}$ and one oxygen, $\mathrm{O}_{\text {phenolate}}$ ) and one dipic ligand (through two $\mathrm{O}_{\text {carboxylate }}$ oxygens and one $\mathrm{N}_{\text {pyridine }}$ nitrogen) with a pseudo-octahedral geometry. Both ligands are arranged aproximately orthogonal to each other, where the dipic ligand atoms and the $\mathrm{N}_{\text {imine }}$ are located in the equatorial plane, and the $\mathrm{O}_{\text {phenolate }}$ and $\mathrm{N}_{\text {quinoline }}$ in the axial plane. Notably, the $\mathrm{N}_{\text {dipic }}-\mathrm{Fe}-\mathrm{N}_{\text {imine }}$ angles deviate more for $\mathbf{3}$ and $\mathbf{4}$, which also show higher octahedral distortion parameters $\left(\Sigma^{43,44}\right.$ and $\left.\Theta^{45}\right)$ (Table 1$)$. The Fe-O and Fe-N distances are ca. 1.85-2.05 $\AA$ and 2.05-2.10 $\AA$ A respectively, and consistent with a HS Fe ${ }^{\text {III }}$ center in all cases.

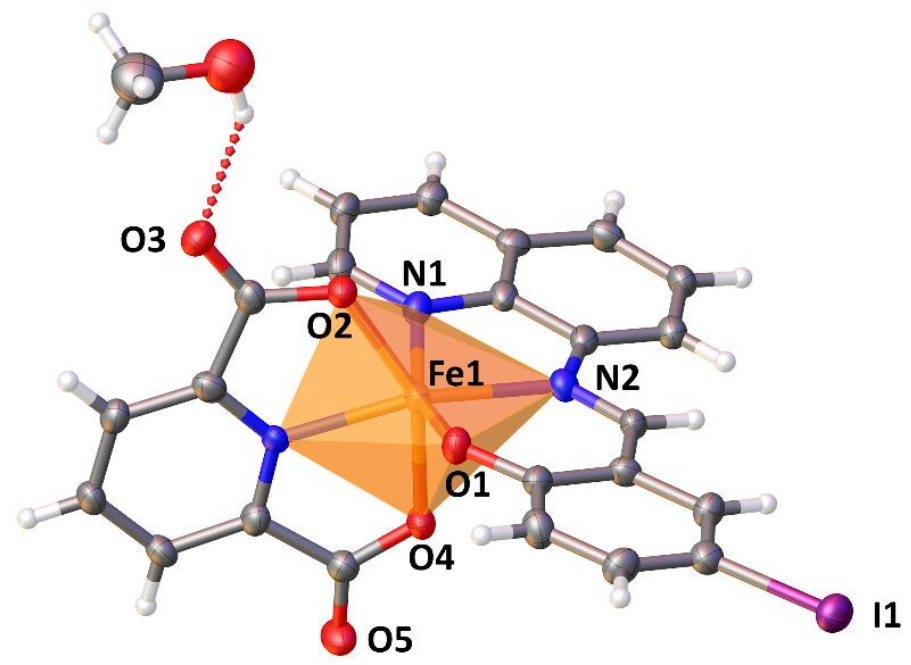

Figure 2 Asymmetric unit in [Fe(qsal-I)(dipic)] $\cdot \mathrm{MeOH} 4$ at room temperature. Ellipsoids are drawn at $50 \%$.

Table 1 Selected Fe-N/O bond length $(\AA)$, unit cell volume $\left(\AA^{3}\right)$ and octahedral distortion for 1-4.

\begin{tabular}{|c|c|c|c|c|}
\hline & $\mathbf{F}$ & $\mathrm{Cl}$ & $\mathrm{Br}$ & I \\
\hline & $150 \mathrm{~K}$ & $150 \mathrm{~K}$ & $150 \mathrm{~K}$ & $300 \mathrm{~K}$ \\
\hline Fe-O1 $1_{\text {phenolate }}$ & 1.883 & 1.891 & 1.898 & 1.904 \\
\hline Fe-N1 $1_{\text {quin }}$ & 2.147 & 2.149 & 2.138 & 2.142 \\
\hline Fe-N2 ${ }_{\text {imine }}$ & 2.092 & 2.096 & 2.124 & 2.119 \\
\hline Fe-O2 dipic & 2.028 & 1.986 & 2.051 & 2.049 \\
\hline
\end{tabular}




\begin{tabular}{|c|c|c|c|c|}
\hline Fe-O4 dipic & 2.067 & 2.058 & 2.046 & 2.044 \\
\hline Fe-N3 ${ }_{\text {dipic }}$ & 2.061 & 2.052 & 2.079 & 2.079 \\
\hline N1-Fe-O1 & 162.96 & 162.87 & 158.29 & 158.31 \\
\hline N2-Fe-N3 & 166.91 & 168.75 & 158.30 & 158.72 \\
\hline O2-Fe-O4 & 150.86 & 152.65 & 150.34 & 150.40 \\
\hline Planes angle & 81.73 & 85.52 & 89.09 & 89.52 \\
\hline$V / \AA^{3}$ & 1070.3 & 1102.9 & 2128.8 & 2172.2 \\
\hline$\Sigma-\mathrm{Fe}^{\mathrm{a}}$ & 101 & 98 & 119 & 105 \\
\hline$\Theta-F e 1^{\mathrm{a}}$ & 386 & 365 & 481 & 413 \\
\hline
\end{tabular}

${ }^{\mathrm{a} C a l c u l a t e d}$ using OctaDist. ${ }^{46}$

\section{Structural packing}

The Fe(III) centers are connected by $\pi-\pi$ and $\mathrm{C}-\mathrm{H} \cdots \mathrm{O}$ interactions resulting in the formation of a 1D chain (Figure 3). Interestingly, the qsal-X ligands only overlap with each other suggesting that the $\pi$ $\pi$ interactions in these ligands represent robust synthons. The self-sorting observed in the chains leaves the dipic ligands to overlap. However, the type of overlap is more varied, with $\pi-\pi$ interactions in $\mathbf{3}$ and $\mathbf{4}$, but $C=0 \cdots \pi$ interactions in $\mathbf{1}$ and $\mathbf{2}$. Although $\mathrm{C}=0 \cdots \pi$ interactions are rarer than $\pi-\pi$ interactions in $\left[\mathrm{M} \text { (dipic) }{ }_{2}\right]^{\text {n- }}$ complexes, they have been reported by Mirzaei and Frontera and are found to be attractive. ${ }^{30,47}$ This change in the type of interactions which link the dipic ligands in the 1D chain result in a quasi-linear disposition of the metal centers in $\mathbf{1}$ and $\mathbf{2}$, and a square cross-section, while a zig-zag disposition and rectangular cross-section is observed for $\mathbf{3}$ and $\mathbf{4}$ (Figure S3).

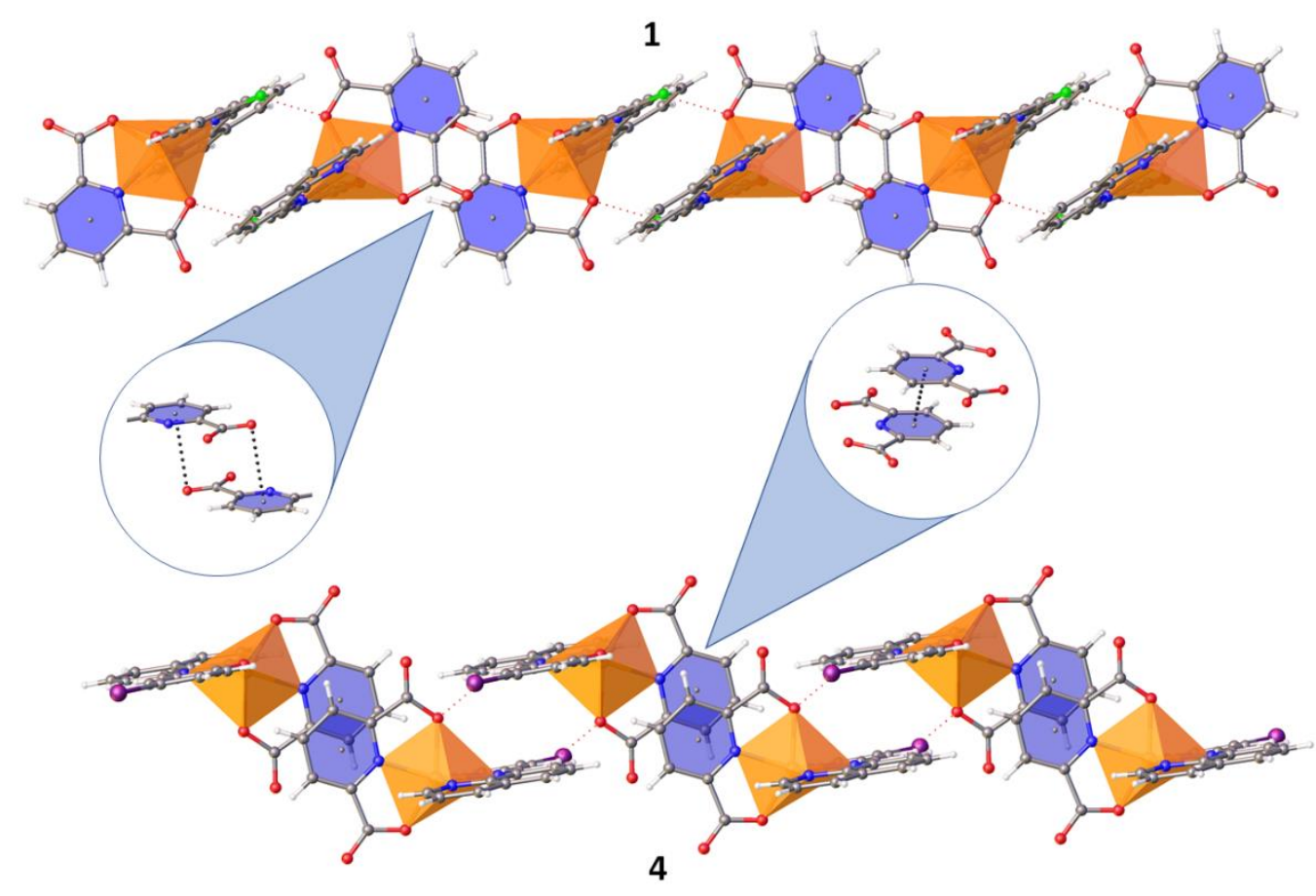

Figure 3 Structure representation of the supramolecular 1D chain for $\mathbf{1}$ (top) and $\mathbf{4}$ (bottom). 
These differences are clearly caused by the halogen substituent. In the case of $\mathbf{1}$ and $\mathbf{2}$, the 1D chain is connected through hydrogen bonds with two neighboring chains forming 2D planes. These interactions involve the halogen group and the quinoline moiety which interact through $\mathrm{C}-\mathrm{H} \cdots \mathrm{X}$ interactions $(\mathrm{X}=\mathrm{F}, \mathrm{Cl})$ and also by $\pi \cdots \mathrm{Cl}$ interactions in the case of $\mathbf{2}$ (Figure 4, left). The final supramolecular 3D structure is achieved through $\pi-\pi$ interactions between the quinoline moieties. The network is further supported by weak $\mathrm{C}-\mathrm{H} \cdots \mathrm{O}$ interactions involving the quinoline and dipic moieties (Figure S4). For 3 and 4, the 1D chains are connected to four neighboring chains by $0 \cdots X$ halogen bonds $(\mathrm{X}=\mathrm{Br}, \mathrm{I}, \mathrm{ca}$. 3.15-3.17 $\AA$ ) involving the halogen group and the dipic keto group (Figure 4, right). Using the normalized contact method ${ }^{48}$ we find that $\mathrm{Nc}$ is 0.94 and 0.90 for $\mathbf{3}$ and 4, respectively, indicating that the halogen bond in $\mathbf{4}$ is substantially stronger than in $\mathbf{3}$. In contrast to $\mathbf{1}$ and $\mathbf{2}$, the halogen bond allows the formation of the complete 3D supramolecular network (Figure S5). As with 1 and $\mathbf{2}$, the 3D network is supported by $\pi$ - $\pi$ interactions between the quinoline moieties, however no $\mathrm{C}-\mathrm{H} \cdots \mathrm{O}$ interactions are observed. We note that, $\mathrm{C}-\mathrm{H} \cdots \mathrm{X}$ interactions are still observed in $\mathbf{3}$ and $\mathbf{4}$, but they are substantially weaker than the halogen bonds and it is evident that the latter determines the supramolecular connectivity in the structures (Table S2).

1

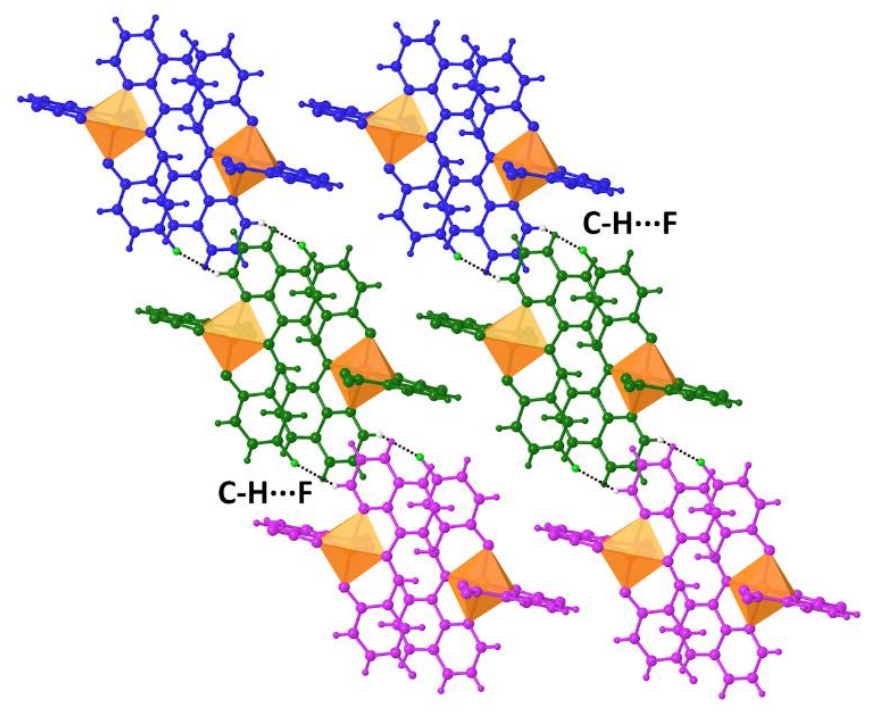

4

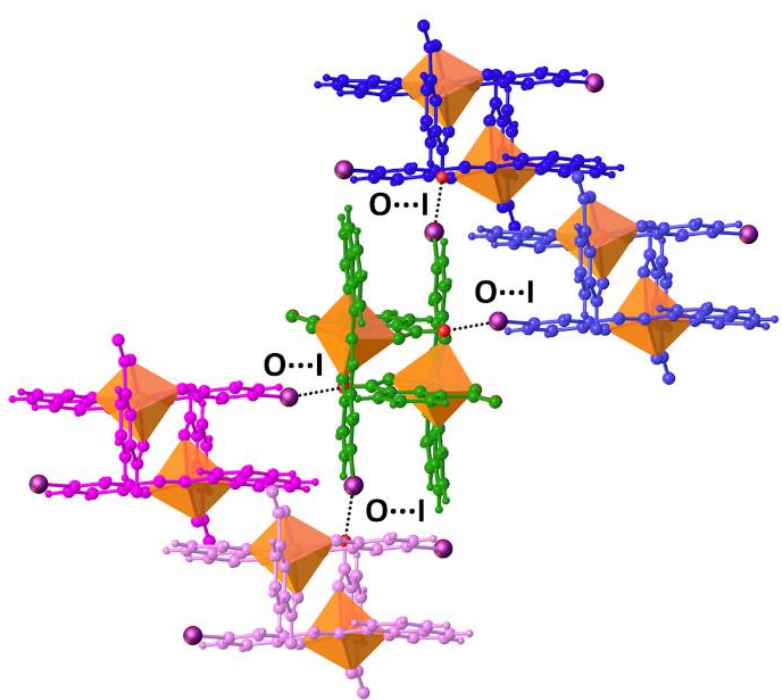

Figure 4 Structure representation of the neighboring chain interactions for $\mathbf{1}$ (left) and $\mathbf{4}$ (right). Different chains are represented by different colors.

Table 2 Intermolecular interactions $\pi-\pi, C=O \cdots \pi, X \cdots C-H$ and $X \cdots O$ for 1-4 ( $\AA$ ).

\begin{tabular}{ccccc}
\hline & F & Cl & Br & I \\
\hline $\begin{array}{c}\text { 1D chain } \\
\pi-\pi\end{array}$ & & & & \\
$\begin{array}{c}\text { dipic } \\
\text { C=0 } \cdots \pi\end{array}$ & - & - & 3.553 & 3.567 \\
dipic & 3.322 & 3.350 & - & -
\end{tabular}




\begin{tabular}{ccccc}
\hline$\frac{\text { 2D and 3D }}{\mathrm{X} \cdots \mathrm{C}-\mathrm{H}}$ & 2.437 & 2.844 & 3.008 & 3.058 \\
$\mathrm{X} \cdots \mathrm{O}$ & - & - & 3.166 & 3.151 \\
\hline
\end{tabular}

The $0 \cdots X$ halogen bond force the planes, in $\mathbf{3}$ and $\mathbf{4}$, to be perpendicular to each other. This is in contrast to $\mathbf{1}$ and $\mathbf{2}$, where the $\mathrm{C}-\mathrm{H} \cdots \mathrm{X}$ interactions establish a parallel arrangement (Figure 5 ). In both cases, channels are formed between the planes where the methanol solvent molecules are located. Each molecule connects the different planes interacting with three different chains by one hydrogen bond ( $c a .1 .83-2.26 \AA$ ) and two $\mathrm{O} \cdots \mathrm{H}$ interactions ( $c a .2 .40-2.70 \AA$ ). Hirshfeld surface analysis performed using CrystalExplorer17, ${ }^{49}$ confirms that $\mathrm{O} \cdots \mathrm{X}$ halogen bonding is only present in $\mathbf{3}$ and $\mathbf{4}$, with similar contributions in both cases (Figure S6 and Table S3). In contrast, C-H $\cdots$ X interactions are present in all complexes but show more defined peaks in $\mathbf{1}$ and $\mathbf{2}$.
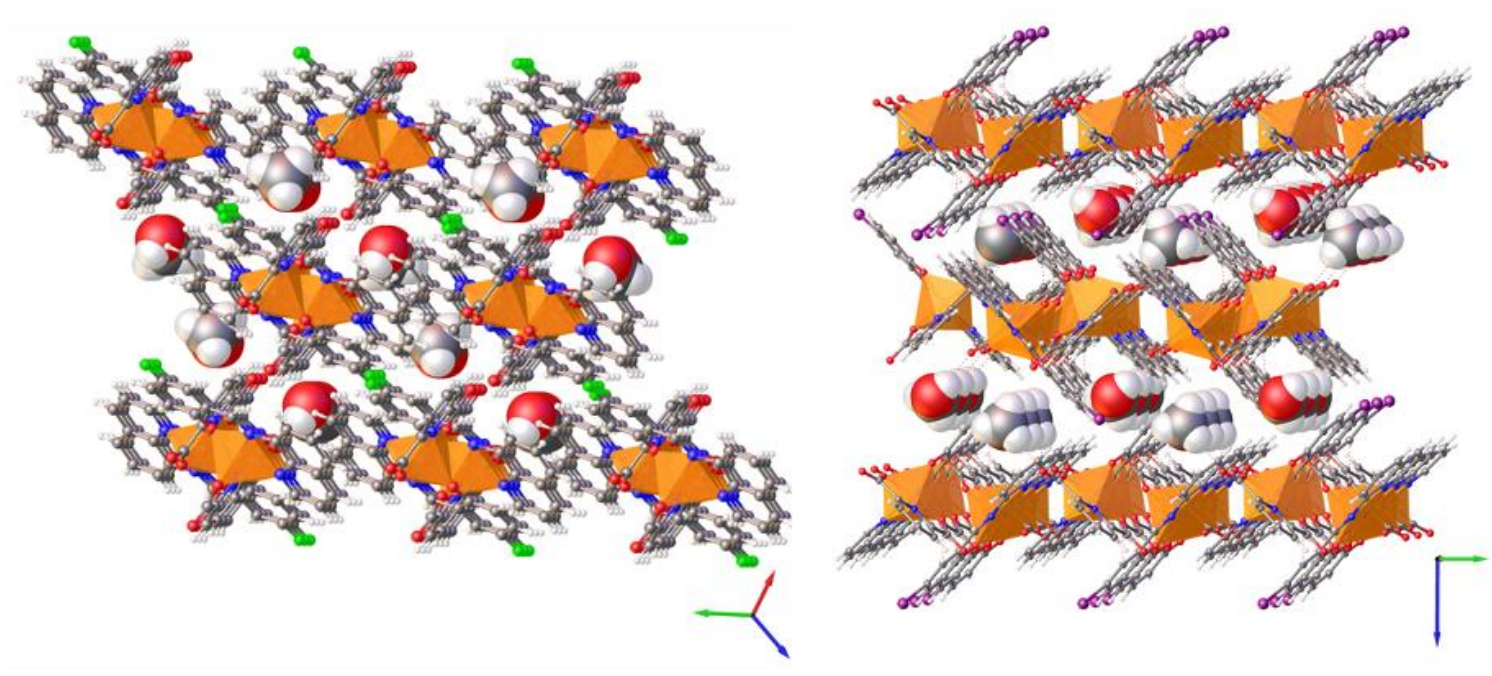

Figure 5 View of the methanol solvent in the pockets between the planes of 1 (left) and $\mathbf{4}$ (right).

\section{Theoretical analysis}

The understand the reason for the difference in the structures we performed a theoretical analysis of the different intermolecular interactions present in the crystal structures of 1-4. The molecular electrostatic potential (MEP) maps of the four complexes (Figure 6) show electron density is concentrated around the carboxylate groups while the hydrogen atoms of the aromatic rings show a clear electron density depletion. More striking differences are found at the halogen atom, going from a negative value of the electron density at $F(-14.7 \mathrm{kcal} / \mathrm{mol})$ to a marked $\sigma$-hole at I $(+17.9 \mathrm{kcal} / \mathrm{mol})$. This different distribution of the electron density explains the preference of $\mathbf{3}$ and $\mathbf{4}$, with a $\sigma$-hole associated with $\mathrm{Br}$ and $\mathrm{I}$, to establish halogen bonds in their crystal structures. 


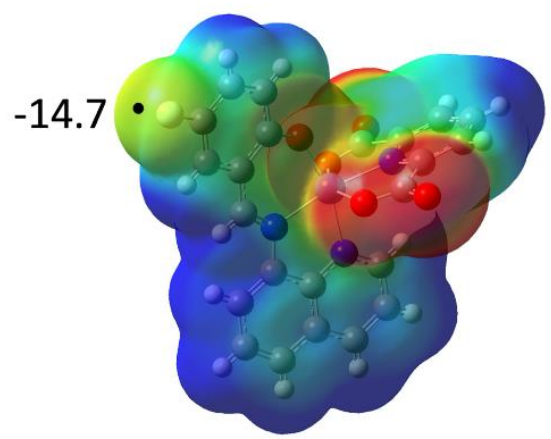

1

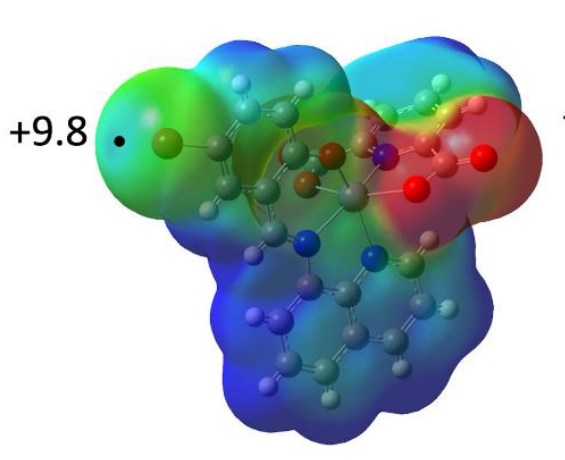

3

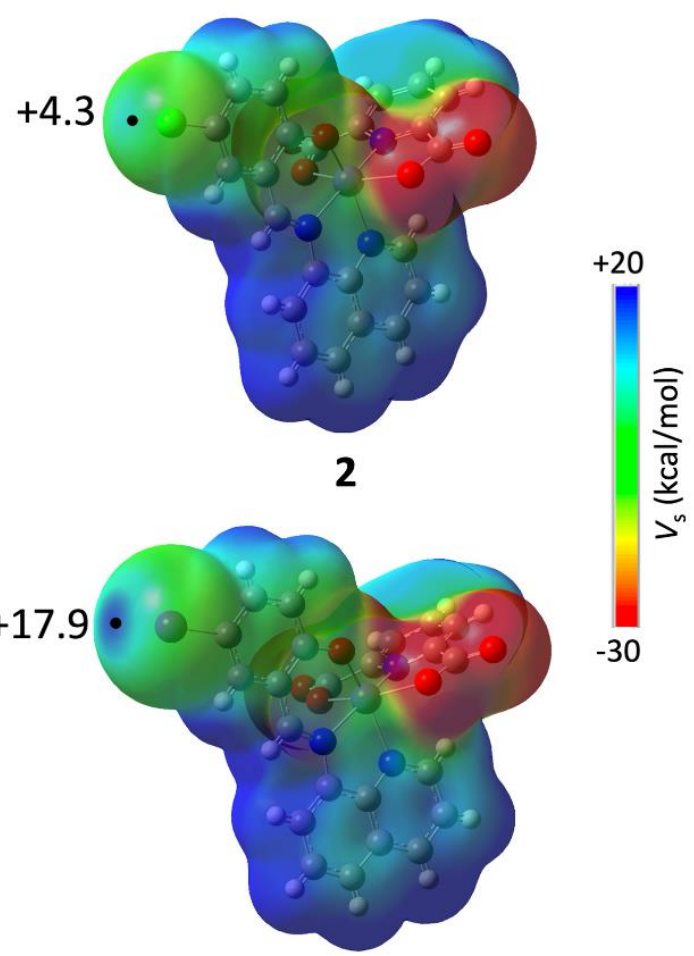

4

Figure 6. Molecular electrostatic potential (MEP) maps for complexes 1-4. Values of the EP at the extension of the $\mathrm{C}-\mathrm{X}(\mathrm{X}=\mathrm{F}, \mathrm{Cl}, \mathrm{Br}, \mathrm{I})$ bond, indicated with a black point, are given in $\mathrm{kcal} / \mathrm{mol}$.

To further understand the supramolecular assemblies of the four crystal structures, we have analysed the topology of the electron density of 1-4 by means of the QTAIM theory ${ }^{50}$ (complete results can be found in Table S4). For each structure, two different dimers have been selected involving the short contacts associated with the $1 \mathrm{D}$ chains and 2D/3D networks, namely $\mathrm{H}$-bond and $\mathrm{C}=\mathrm{O} \cdots \pi$ in 1-2 and $\mathrm{X}$-bond and $\pi \cdots \pi$ in 3-4 (see Table S4). The first observation is that the $\mathrm{C}-\mathrm{H} \cdots \mathrm{X}$ hydrogen bond shows a bond path in the four crystal structures (1-4) while the $\mathrm{C}=\mathrm{O} \cdots \mathrm{X}$ halogen bond is only present in $\mathbf{3}$ and $\mathbf{4}$ (Figure 7). Interestingly, the small vdW radius of the fluorine atom, with a shorter $\mathrm{C}-\mathrm{F} \cdots \mathrm{H}$ distance with respect to the $\mathrm{Cl}$ analogue (2.437 and $2.844 \AA$, respectively), allows for the formation of a homonuclear dihydrogen interaction $\mathrm{C}-\mathrm{H} \cdots \mathrm{H}-\mathrm{C}(2.812 \AA)$ in $\mathbf{1}$ that contributes to the overall stabilisation of the system. ${ }^{51}$ The calculated interaction energies are in the range - 2.5 - $3.0 \mathrm{kcal} / \mathrm{mol}$ for $1-3$, while it increases up to $-4.18 \mathrm{kcal} / \mathrm{mol}$ in 4 . The strong character of the halogen bond in $\mathbf{4}$ is further confirmed by the highest values of the electron density at the bond critical point $(B C P=0.011$ a.u. $)$ among all the studied $B C P$ s. Also the value of the delocalization index $(D I(O, I)=$ $0.108)$, associated with the number of electrons delocalized in the bond, indicates a greater degree of covalency. 


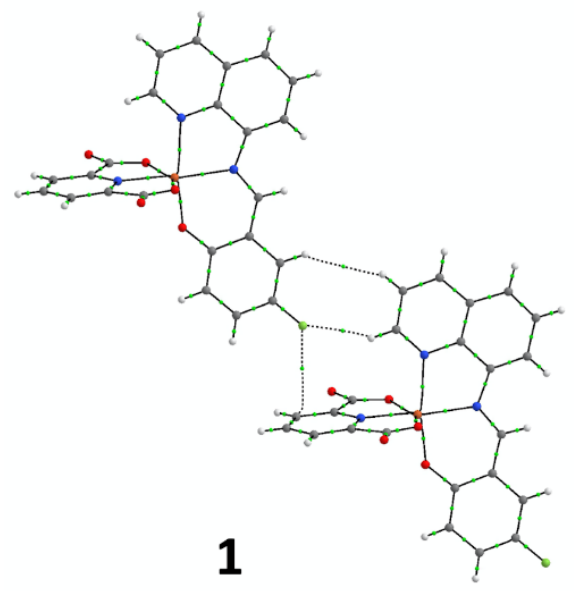

$\Delta \mathrm{E}_{\mathrm{int}}=-2.73 \mathrm{kcal} / \mathrm{mol}$

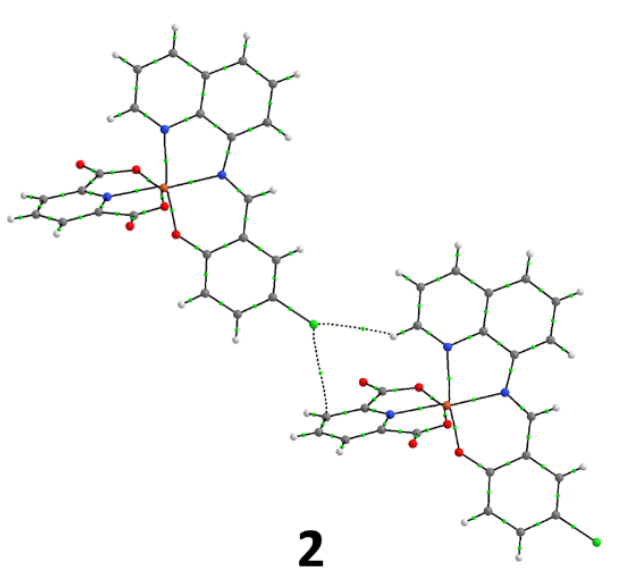

$\Delta \mathrm{E}_{\text {int }}=-2.50 \mathrm{kcal} / \mathrm{mol}$
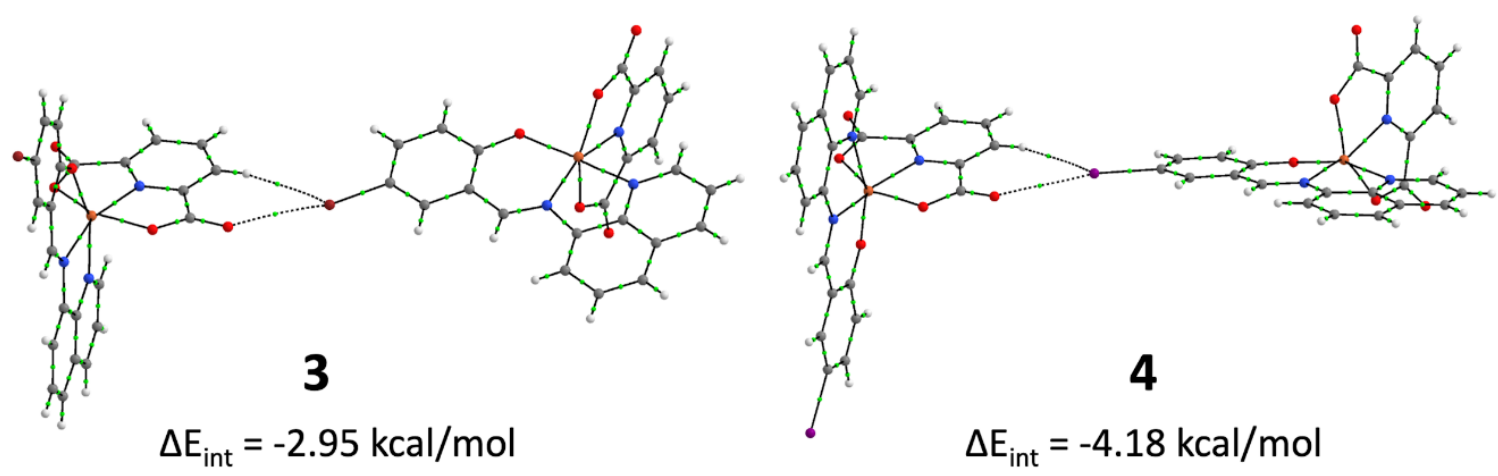

Figure 7. QTAIM graphs of the dimers connected via $\mathrm{C}-\mathrm{H} \cdots \mathrm{X}$ hydrogen bonds $(\mathbf{1}, \mathbf{2})$ and $\mathrm{C}=\mathrm{O} \cdots \mathrm{X}$ halogen bonds $(3,4)$. The interaction energies $\left(\Delta \mathrm{E}_{\text {int }}\right)$ have been calculated by means of the supermolecule approach at the B3LYP-D3/def2-TZVP level.

The QTAIM graphs of the stacked dimers in $\mathbf{1 - 4}$ are depicted in Figure $\mathbf{8}$. While $\mathbf{1}$ and $\mathbf{2}$ are clearly dominated by $\mathrm{C}=\mathrm{O} \cdots \pi$ interactions, only in $\mathbf{2}$ this is confirmed by the corresponding $\mathrm{O} \cdots \mathrm{C}$ bond paths. Conversely, in $\mathbf{1}$, we face $\mathrm{C} \cdots \mathrm{C}$ bond paths. This does not necessarily imply the absence of the aforementioned $\mathrm{C}=\mathrm{O} \cdots \pi$ interaction because small differences in the contact distances between rings can slightly modify the topology of the electron density and, thus, the atoms connected by bond paths. In this case, the angle defined by the $\mathrm{C}=\mathrm{O}$ group and the centroid of the pyridine ring is $93.8^{\circ}$ in $\mathbf{1}$ and $97.7^{\circ}$ in $\mathbf{2}$, leading to a shorter $\mathrm{C}=0 \cdots \mathrm{C}$ distance in $\mathbf{2}$, which explains the differences between the bond paths in $\mathbf{1}$ and $\mathbf{2}$. Furthermore, in all cases the stacked rings are accompanied by two bond paths associated with $\mathrm{C}-\mathrm{H} \cdots \mathrm{O}$ hydrogen bonds. It is also worth noting that the interaction energies, $13.7--15.2 \mathrm{kcal} / \mathrm{mol}$, are significantly greater than in the halogen/hydrogen-bound dimers, probably due to the enhanced dispersion energy associated with the large $\pi-\pi$ stacked area. 


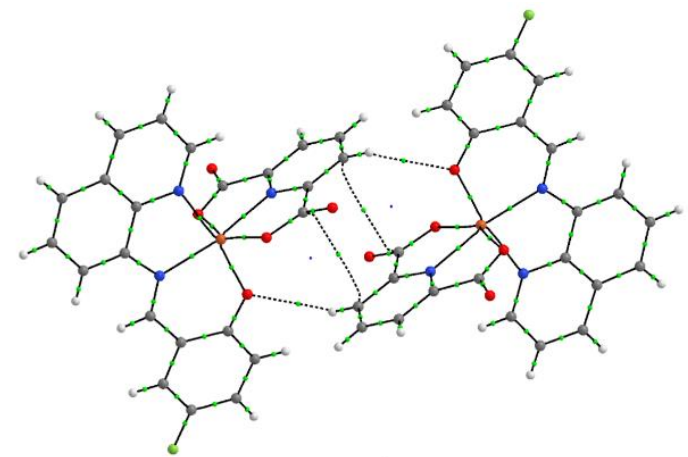

1

$\Delta \mathrm{E}_{\mathrm{int}}=-14.12 \mathrm{kcal} / \mathrm{mol}$

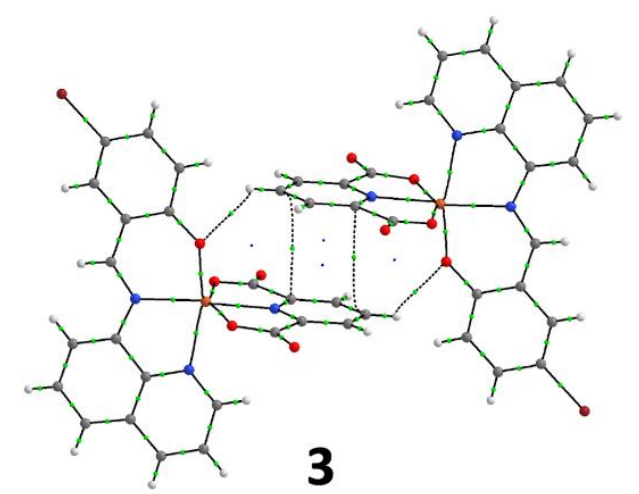

$\Delta \mathrm{E}_{\mathrm{int}}=-14.94 \mathrm{kcal} / \mathrm{mol}$

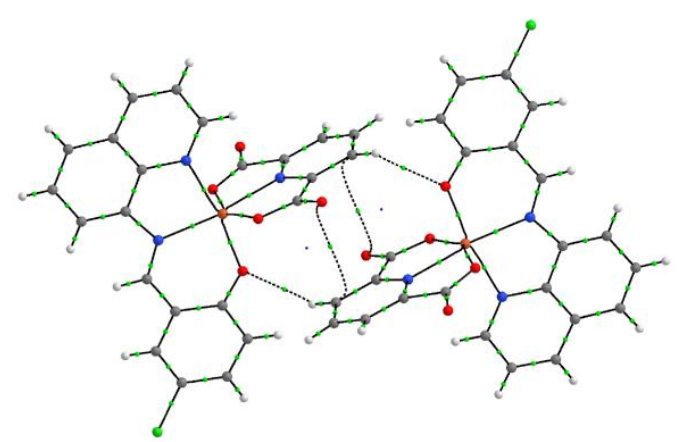

2

$\Delta \mathrm{E}_{\mathrm{int}}=-13.69 \mathrm{kcal} / \mathrm{mol}$

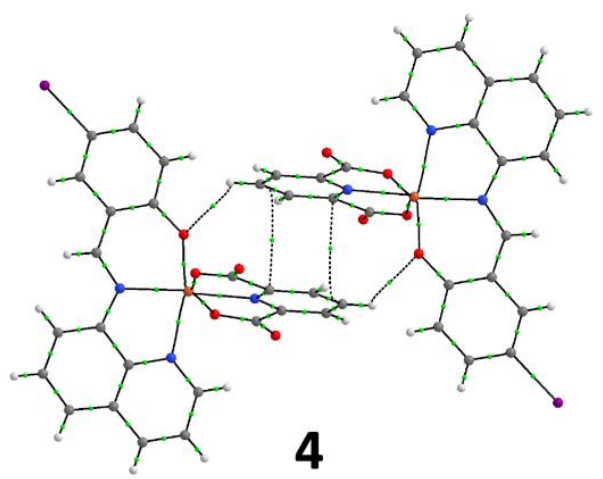

$\Delta \mathrm{E}_{\text {int }}=-15.20 \mathrm{kcal} / \mathrm{mol}$

Figure 8. QTAIM graphs of the stacked dimers 1-4. The interaction energies $\left(\Delta \mathrm{E}_{\text {int }}\right)$ have been calculated by means of the supermolecule approach at the B3LYP-D3/def2-TZVP level.

We have further inspected the electron density of the dimers under study with the noncovalent interaction $(\mathrm{NCl})$ index method. The $\mathrm{NCl}$ method allows the identification of regions of attractive or repulsive interaction by visualization of the electron density and its derivatives. The gradient $\mathrm{NCl}$ isosurfaces for the hydrogen/halogen bonded and the stacked dimers are shown in Figures 9 and 10, respectively. In 1 and $\mathbf{2}$ the dimers are connected via hydrogen bonds (Figure 9), we can identify the low density/low gradient regions associated with the $\mathrm{C}-\mathrm{H} \cdots \mathrm{X}$ and $\mathrm{C}-\mathrm{X} \cdots \pi(\mathrm{X}=\mathrm{F}$, $\mathrm{Cl}$ ) along with the dihydrogen interaction present in 1 . A region of attractive $\mathrm{C}-\mathrm{H} \cdots \mathrm{C}$ interaction, which usually accompanies $\mathrm{C}-\mathrm{H} \cdots \mathrm{H}-\mathrm{C}$ contacts, is also found nearby. ${ }^{52}$ In $\mathbf{3}$ and $\mathbf{4}$, the $\mathrm{C}=\mathrm{O} \cdots \mathrm{Br}$ and $\mathrm{C}=\mathrm{O} \cdots \mathrm{I}$ halogen bonds are clearly visible, in good agreement with the QTAIM results. On the other hand, in the stacked dimers of Figure 10, the green regions indicating an attractive interaction are significantly larger, especially in $\mathbf{3}$ and $\mathbf{4}$, in line with the high interaction energies calculated for these systems. 

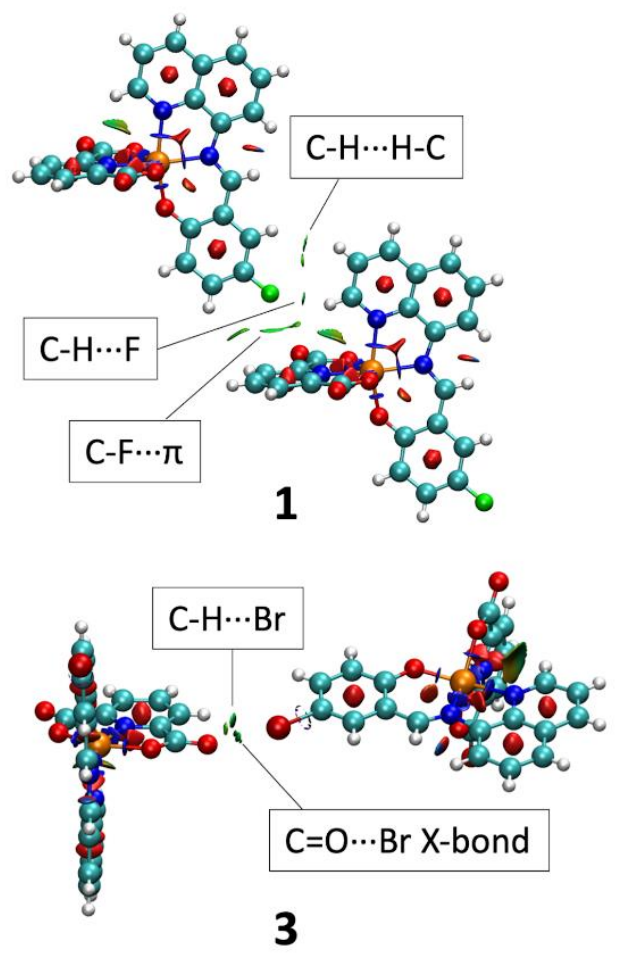
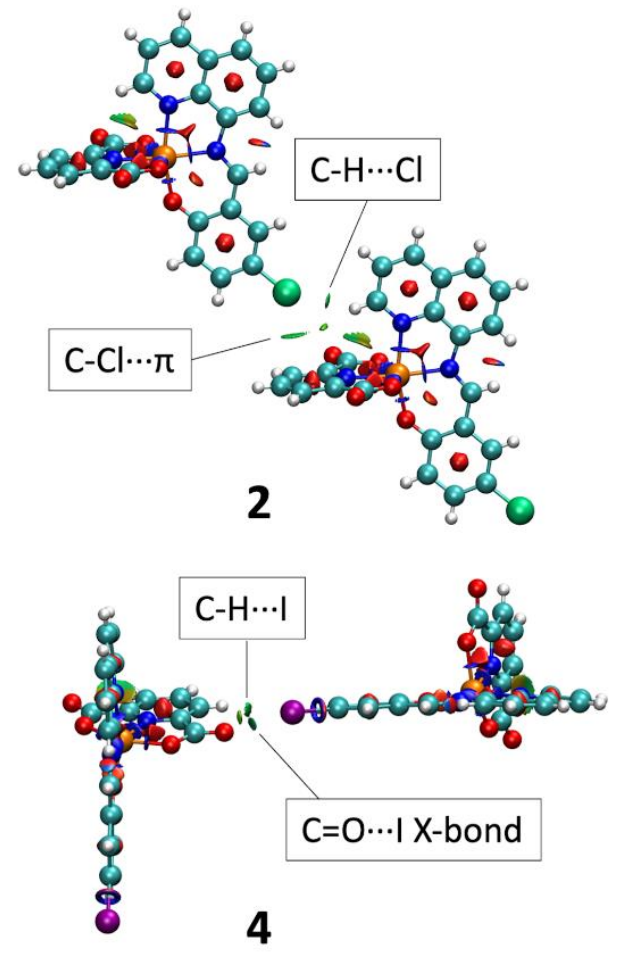

Figure 9. $\mathrm{NCl}$ plots of the dimers connected via $\mathrm{C}-\mathrm{H} \cdots \mathrm{X}$ hydrogen bonds $(\mathbf{1}, \mathbf{2})$ and $\mathrm{C}=\mathrm{O} \cdots \mathrm{X}$ halogen bonds $(3,4)$.

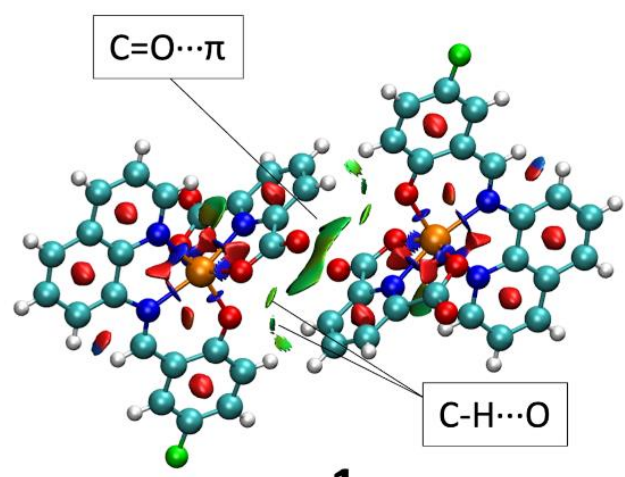

1

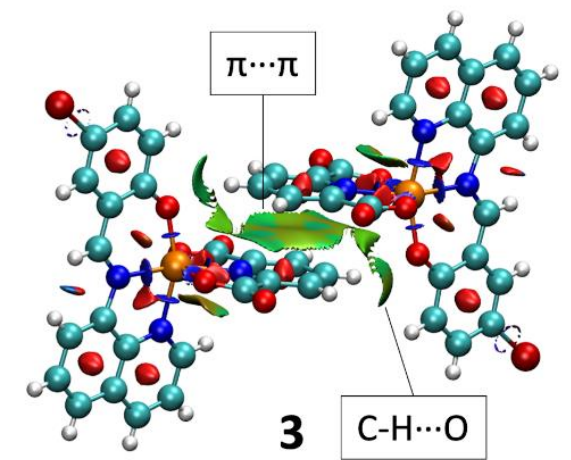

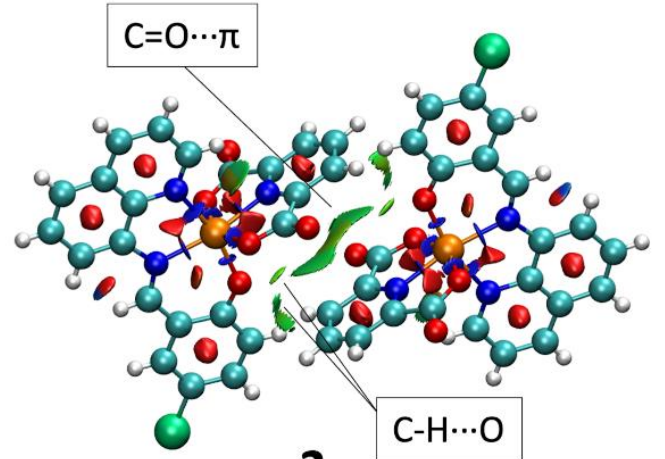

2

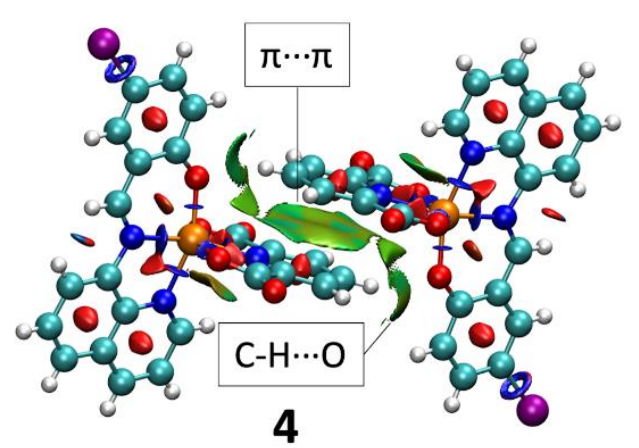

Figure 10. $\mathrm{NCl}$ plots of the stacked dimers 1-4. 


\section{Electrochemical studies}

Cyclic voltammetry (CV) was used to characterize the redox properties of 1-4 at different scan rates and the values are listed in Table S4. All systems show the same general behavior: a reversible reduction around $-0.6 \mathrm{~V}$ (vs $\mathrm{Fc} / \mathrm{Fc}^{+}$) corresponding to the $\mathrm{Fe}^{3+} / \mathrm{Fe}^{2+}$ couple and two pseudo-reversible reduction processes at -2.1 and $-2.0 \mathrm{~V}$, attributed to reduction of the qsal-X ligand (Figures 11 and S8). No oxidation processes are observed in any systems within the electrochemical window of DCM (Figure S8). This is in contrast to other [Fe(qsal-X $\left.)_{2}\right]^{+}$complexes or free Hqsal-X ligands, where an irreversible oxidation peak is observed around $0.7 \mathrm{~V}$ (vs Fc/Fc ${ }^{+}$) (Figure S9). ${ }^{53}$ The halogen is found to slightly influence the position of the $\mathrm{Fe}^{3+} / \mathrm{Fe}^{2+}$ redox couple $\left\{\mathrm{E}^{\prime \circ}(\mathrm{F}):-0.67 ; \mathrm{E}^{\prime \circ}(\mathrm{Cl}):-0.62 ; \mathrm{E}^{\prime \circ}(\mathrm{Br}):-0.61\right.$; $\mathrm{E}^{\prime \circ}(\mathrm{I}):-0.64 \mathrm{~V}$ \}. A plot of the Hammett parameter, $\sigma_{\mathrm{p}}$ against $\mathrm{E}^{\prime \circ}$ gives a good correlation, although more complexes would be needed to confirm this (Figure S10).

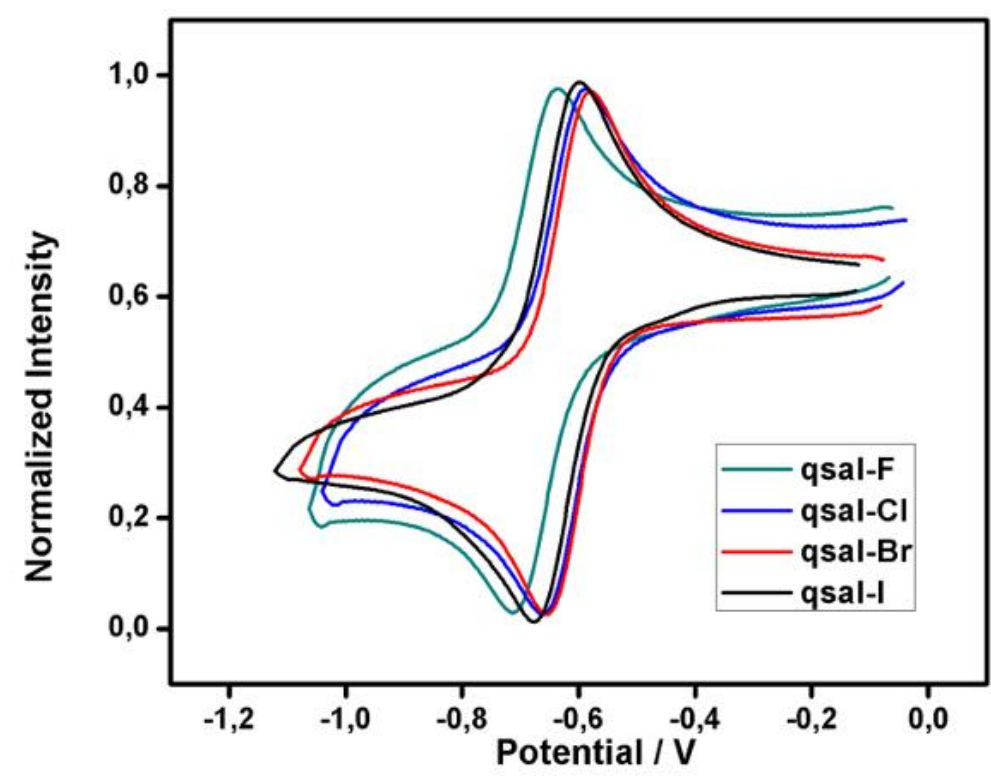

Figure 11 Cyclic voltammograms $\left(\mathrm{Fe}^{3+} / \mathrm{Fe}^{2+}\right.$ redox peak) of 1-4 in DCM containing $0.1 \mathrm{M}$ of TBAPF 6 (scan rate $100 \mathrm{mV} / \mathrm{s}$ ) vs $\mathrm{Fc} / \mathrm{Fc}^{+}$.

\section{Conclusions}

In conclusion, these studies demonstrate that the $\mathrm{C}=\mathrm{O}$ group is an effective halogen bond acceptor. The structural studies further shed light on the limits of where halogen bonding becomes relevant compared to hydrogen bonding, which in the current series is only for the bromo and iodo substituents. Computational analysis supports the supramolecular assemblies in each of the compounds and corroborates the stronger character of the halogen bond for the iodo substituent. Furthermore, electrochemical studies reveal that the halogen is able to subtly tune the $\mathrm{Fe}^{3+} / \mathrm{Fe}^{2+}$ redox couple, showing a linear correlation with the Hammett parameter. We are currently exploring 
further systems where we might exploit these discoveries in the design of more functional supramolecular networks.

\section{Acknowledgements}

We gratefully acknowledge the Thailand Research Fund (BRG6180008) and the Thailand Science Research and Innovation Fund (Grant No. WU-FF 64101) for funding this research. Walailak University is thanked for a postdoctoral research fellowship to R.D.T. The National Science Technology and Innovation Policy Office for Integrated Research and Innovation Plan (Grant No. 256113A3050001) is thanked for funds to purchase an X-ray diffractometer.

\section{Author Contributions}

\section{Corresponding Authors}

David J. Harding, Functional Materials and Nanotechnology Centre of Excellence, Walailak University, Thasala, Nakhon Si Thammarat, 80160, Thailand; ORCiD orcid.org/0000-0001-88662401; E-mail: hdavid@mail.wu.ac.th.

Phimphaka Harding, Functional Materials and Nanotechnology Centre of Excellence, Walailak University, Thasala, Nakhon Si Thammarat, 80160, Thailand; ORCiD orcid.org/0000-0002-7253316X; E-mail: kphimpha@mail.wu.ac.th.

\section{Authors}

Raúl Díaz-Torres, Functional Materials and Nanotechnology Centre of Excellence, Walailak University, Thasala, Nakhon Si Thammarat, 80160, Thailand; ORCiD orcid.org/0000-0002-14066436.

Jorge Echeverría, Departament de Química Inorgànica i Orgànica \& IQTC-UB, Universitat de Barcelona, Martí i Franquès, 1-11, 08028 Barcelona, Spain; ORCiD orcid.org/0000-0002-8571-0372.

Oliver Loveday, Departament de Química Inorgànica i Orgànica \& IQTC-UB, Universitat de Barcelona, Martí i Franquès, 1-11, 08028 Barcelona, Spain.

\section{References}

1 G. R. Desiraju, J. J. Vittal and A. Ramanan, Crystal Engineering: A Textbook, Word Scientific, New Jersey, 2011.

2 G. R. Desiraju, J. Am. Chem. Soc., 2013, 135, 9952-67.

3 D. Braga, G. R. Desiraju, J. S. Miller, A. G. Orpen and S. L. Price, CrystEngComm, 2002, 4, 500.

4 K. Biradha, CrystEngComm, 2003, 5, 374-384.

5 C. B. Aakeröy, N. R. Champness and C. Janiak, CrystEngComm, 2010, 12, 22-43.

6 G. Cavallo, P. Metrangolo, R. Milani, T. Pilati, A. Priimagi, G. Resnati and G. Terraneo, Chem. Rev., 2016, 116, 2478-2601.

7 T. Steiner, Angew. Chem. Int. Ed., 2002, 41, 48-76.

8 T. Clark, M. Hennemann, J. S. Murray and P. Politzer, J. Mol. Model., 2007, 13, 291-6. 
9 P. Metrangolo, F. Meyer, T. Pilati, G. Resnati and G. Terraneo, Angew. Chem. Int. Ed., 2008, 47, 6114-27.

10 G. Cavallo, P. Metrangolo, T. Pilati, G. Resnati, M. Sansotera and G. Terraneo, Chem. Soc. Rev., 2010, 39, 3772-83.

11 A. Priimagi, G. Cavallo, P. Metroangolo and G. Resnati, Acc. Chem. Res., 2013, 46, 2686-2695.

12 A. Mukherjee, S. Tothadi and G. R. Desiraju, Acc. Chem. Res., 2014, 47, 2514-2524.

13 L. C. Gilday, S. W. Robinson, T. A. Barendt, M. J. Langton, B. R. Mullaney and P. D. Beer, Chem. Rev., 2015, 115, 7118-7195.

14 D. Braga, F. Grepioni, L. Maini and S. d'Agostino, Eur. J. Inorg. Chem., 2018, 2018, 3597-3605.

C. B. Aakeröy, A. S. Sinha, P. D. Chopade and J. Desper, Dalton Trans., 2011, 40, 1216012168.

J. C. Gamekkanda, A. S. Sinha, J. Desper, M. Đaković and C. B. Aakeröy, Crystals, 2017, 7, 226.

17 P. Smart, Á. Bejarano-Villafuerte, R. M. Hendry and L. Brammer, CrystEngComm, 2013, 15, 3160.

D. Cinčić and T. Friščić, CrystEngComm, 2014, 16, 10169-10172.

V. Nemec, L. Fotović, T. Friščić and D. Cinčić, Cryst. Growth Des., 2017, 17, 6169-6173.

I.-R. Jeon, O. Jeannin, R. Clérac, M. Rouzières and M. Fourmigué, Chem. Commun., 2017, 53, 4989-4992.

21 M. C. Pfrunder, A. J. Brock, J. J. Brown, A. Grosjean, J. Ward, J. C. McMurtrie and J. K. Clegg, Chem. Commun., 2018, 54, 3974-3976.

M. C. Pfrunder, J. J. Whittaker, S. Parsons, B. Moubaraki, K. S. Murray, S. A. Moggach, N. Sharma, A. S. Micallef, J. K. Clegg and J. C. McMurtrie, Chem. Mater., 2020, 32, 3299-3234. K. Lisac and D. Cinčić, CrystEngComm, 2018, 20, 5955-5963.

24 A. Reyes Zuluaga, A. J. Brock, M. C. Pfrunder, W. Phonsri, K. S. Murray, P. Harding, A. S. Micallef, K. M. Mullen, J. K. Clegg, D. J. Harding and J. C. McMurtrie, Chem. Mater., 2020, 32, 10076-10083.

25 M. Borovina, I. Kodrin and M. Daković, CrystEngComm, 2018, 20, 539-549.

26 C. B. Aakeröy, N. Schultheiss, J. Desper and C. Moore, CrystEngComm, 2007, 9, 421-426.

27 W. Phonsri, D. J. Harding, P. Harding, K. S. Murray, B. Moubaraki, I. A. Gass, J. D. Cashion, G. N. L. Jameson and H. Adams, Dalton Trans., 2014, 43, 17509-17518.

28 N. Phukkaphan, D. L. Cruickshank, K. S. Murray, W. Phonsri, P. Harding and D. J. Harding, Chem. Commun., 2017, 53, 9801-9804.

29 S. E. Lazaro, A. Alkaş, S. J. Lee, S. G. Telfer, K. S. Murray, W. Phonsri, P. Harding and D. J. Harding, Dalton Trans., 2019, 48, 15515-15520.

30 M. Mirzaei, H. Eshtiagh-Hosseini, Z. Karrabi, K. Molčanov, E. Eydizadeh, J. T. Mague, A. Bauzá and A. Frontera, CrystEngComm, 2014, 16, 5352-5363.

Z. Yousefi, H. Eshtiagh-Hosseini, A. Salimi and A. Janiak, J. Mol. Struct., 2015, 1083, 460-470.

N. Büyükkidan, C. Yenikaya, H. Ilkimen, C. Karahan, C. Darcan, T. Korkmaz and Y. Süzen, J. Mol. Struct., 2015, 1101, 139-146.

33 J. C. MacDonald, P. C. Dorrestein, M. M. Pilley, M. M. Foote, J. L. Lundburg, R. W. Henning, A. J. Schultz and J. L. Manson, J. Am. Chem. Soc., 2000, 122, 11692-11702.

J. Sirirak, W. Phonsri, D. J. Harding, P. Harding, P. Phommon, W. Chaoprasa, R. M. Hendry, T. M. Roseveare and H. Adams, J. Mol. Struct., 2013, 1036, 439-446.

35 Rigaku OD, CrysAlis PRO. Rigaku Oxford Diffraction Ltd, Yarnton, Oxfordshire, England, 2019.

36 G. M. Sheldrick, Acta Crystallogr. Sect. A Found. Crystallogr., 2015, 71, 3-8.

37 G. M. Sheldrick, Acta Crystallogr. Sect. C Struct. Chem., 2015, 71, 3-8.

38 O. V. Dolomanov, L. J. Bourhis, R. J. Gildea, J. A. K. Howard and H. Puschmann, J. Appl. Cryst., 
2009, 42, 339-42.

39 M. J. Frisch, G. W. Trucks, H. B. Schlegel, G. E. Scuseria, M. A. Robb, J. R. Cheeseman, G. Scalmani, V. Barone, G. A. Petersson, H. Nakatsuji, X. Li, M. Caricato, A. V Marenich, J. Bloino, B. G. Janesko, R. Gomperts, B. Mennucci, H. P. Hratchian, J. V Ortiz, A. F. Izmaylov, J. L. Sonnenberg, D. Williams-Young, F. Ding, F. Lipparini, F. Egidi, J. Goings, B. Peng, A. Petrone, T. Henderson, D. Ranasinghe, V. G. Zakrzewski, J. Gao, N. Rega, G. Zheng, W. Liang, M. Hada, M. Ehara, K. Toyota, R. Fukuda, J. Hasegawa, M. Ishida, T. Nakajima, Y. Honda, O. Kitao, H. Nakai, T. Vreven, K. Throssell, J. A. Montgomery Jr., J. E. Peralta, F. Ogliaro, M. J. Bearpark, J. J. Heyd, E. N. Brothers, K. N. Kudin, V. N. Staroverov, T. A. Keith, R. Kobayashi, J. Normand, K. Raghavachari, A. P. Rendell, J. C. Burant, S. S. Iyengar, J. Tomasi, M. Cossi, J. M. Millam, M. Klene, C. Adamo, R. Cammi, J. W. Ochterski, R. L. Martin, K. Morokuma, O. Farkas, J. B. Foresman and D. J. Fox, Gaussian 16, Revision C.01, Gaussian, Inc., Wallingford CT, 2016.

40 S. Grimme, J. Antony, S. Ehrlich and H. Krieg, J. Chem. Phys., 2010, 132, 154104.

41 T. A. Keith, AIMAll, TK Gristmill Software, Overland Park KS, USA, 2019.

42 T. Lu and F. Chen, J. Comput. Chem., 2012, 33, 580-592.

43 M. G. B. Drew, C. J. Harding, V. McKee, G. G. Morgan and J. Nelson, J. Chem. Soc. Chem. Commun., 1995, 1035-1038.

44 P. Guionneau, C. Brigouleix, Y. Barrans, A. E. Goeta, J. F. Létard, J. A. K. Howard, J. Gaultier and D. Chasseau, Comptes Rendus l'Academie des Sci. - Ser. IIC Chem., 2001, 4, 161-171.

45 M. Marchivie, P. Guionneau, J. F. Létard and D. Chasseau, Acta Crystallogr. Sect. B Struct. Sci., 2005, 61, 25-8.

46 R. Ketkaew, Y. Tantirungrotechai, P. Harding, G. Chastanet, P. Guionneau, M. Marchivie and D. J. Harding, Dalton Trans., 2021, 50, 1086-1096.

47 M. Mirzaei, H. Eshtiagh-Hosseini, A. Bauzá, S. Zarghami, P. Ballester, J. T. Mague and A. Frontera, CrystEngComm, 2014, 16, 6149-6158.

48 G. Cavallo, S. Biella, J. Lu, P. Metrangolo, T. Pilati, G. Resnati and G. Terraneo, J. Fluor. Chem., 2010, 131, 1165-1172.

49 M. J. Turner, J. J. McKinnon, S. K. Wolff, D. J. Grimwood, D. Spackman, P. R. Jayatilaka and M. A. Spackman, 2017.

50 R. F. W. Bader, Atoms in Molecules: A Quantum Theory, Oxford University Press, Oxford, 1990.

51 J. Echeverría, G. Aullón, D. Danovich, S. Shaik and S. Alvarez, Nat. Chem., 2011, 3, 323-330.

52 J. Echeverría, G. Aullón and S. Alvarez, Int. J. Quantum Chem., 2017, 117, e25432.

53 D. J. Harding, D. Sertphon, P. Harding, K. S. Murray, B. Moubaraki, J. D. Cashion and H. Adams, Chem. Eur. J., 2013, 19, 1082-90. 
TOC Entry

Interplay of halogen and hydrogen bonding in a series of heteroleptic iron(III) complexes

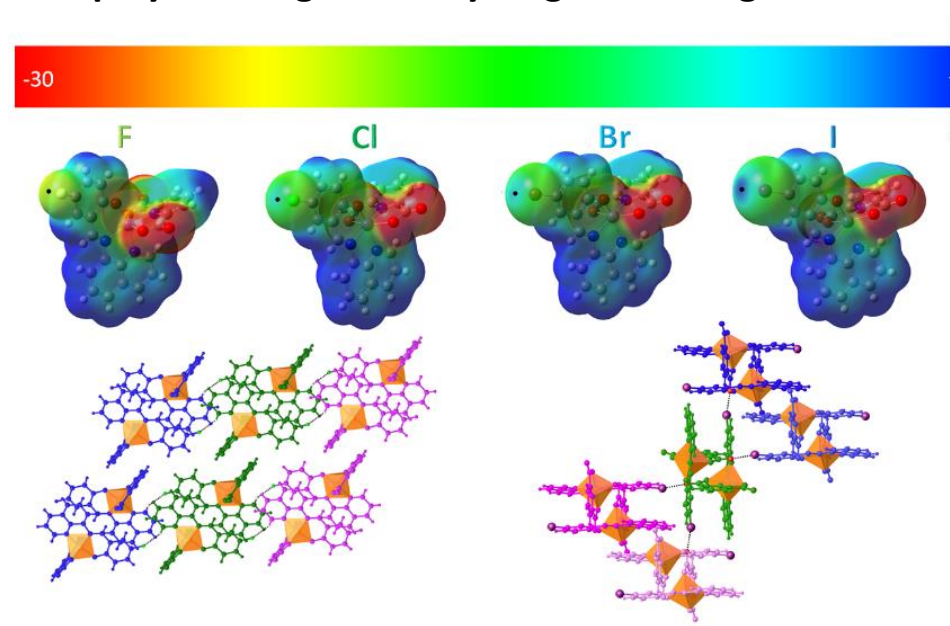

The impact of the halogen substituent on supramolecular preferences that influence packing is explored in a series of heteroleptic iron(III) complexes. 